DOI 10.14746/ppuam.2017.7.06

\author{
Pawee Kwiatkows KI
}

\title{
Soft Law \\ in International Governance
}

\section{Introduction}

The increased role of a wide variety of instruments of different natures and functions, such as resolutions, recommendations, codes of conduct and standards, in the context of the global challenges that require measures of a supranational character to be taken, is accompanied by theoretical reflection on the concept of soft law and its place in the system of the sources of public international law. Soft law, as a generic term developed to cover a wide range of new international instruments established after World War II, was announced in the legal discourse in the middle seventies, and it was based on the distinction between formal and paralegal sources of law. Although resolutions, recommendations, codes of conduct and standards play a special role in influencing international and domestic legal systems, the term 'soft law' is perceived to be unclear. On the other hand, despite this criticism, it is commonly used in publications devoted to all the instruments that are difficult to subsume under a single formula. Taking into consideration all the assumptions presented above, the scope of this article is to draw up the concepts of soft law most commonly used in legal discourse - positivist, rational and constructivist - and to apply them to contemporary practice in the field of genetic data, within international and domestic legal systems.

\section{The Positivist Concept of Soft Law}

In the literature, the most widely accepted definition of the group of international instruments that fall under the concept of 'soft law', which assumes their non-binding character, is based on the adoption of a binary criterion that enables a distinction to be made between two types of international public law norm. The norms established in international agreements and those expressed in international custom are treated as legally binding, while resolutions, opinions and recommendations are not assigned this status. 
94 | Adam Mickiewicz University Law Review

The binary criterion separating these two types of regulation is referred to by, inter alia, Wolfgang Reinicke and Jan Martin Witte ${ }^{1}$ in Commitment and Compliance: The Role of Non-Binding Norms in the International Legal System, and Francis Snyder ${ }^{2}$ in Soft Law and International Practice in the European Community. In the former book, Reinicke and Witte adopted the binary criterion for distinguishing between international regulations in order to analyze the role of soft law in the human rights system, environmental law, arms control, and in the spheres of commerce and finance, thereby revealing the role of soft law in ensuring that states comply with legal regulations. This analysis is accompanied by argumentation in the style of legal-dogmatics, in which Reinicke and Witte formulate the definition of soft law as non-binding legal agreements. ${ }^{3}$ While these authors have focused on international agreements, Snyder proposes a broader approach, defining soft law as rules of conduct that in principle do not possess legally binding force, but which do have practical outcomes. ${ }^{4}$

\section{The Rational Concept of Soft Law}

Theoretical concepts that can be subsumed under the paradigm of institutional rationalism frame the distinctions between legal instruments in terms of the choices made by the international community. The approach takes into account the preferences of social actors, and is at the same time informed by a neo-utilitarian view of the world ${ }^{5}$. This entails evaluating the process through which legal instruments are created, focusing on the strategies which constitute an expression of these preferences. ${ }^{6}$ This approach places the focus on states, exploring how the institutions of international law fulfil the interests of states by resolving the challenges that require collective action. As David Trubek, Patrick Cottrell and Mark Nance observe, the norms established in this way are intended to stabilize the expectations of social actors. ${ }^{7}$ These authors, while analyzing the proposals for the interpretation of soft law expressed from the perspective of institutional rationalism, focus on the catalogue of causes found in the literature on the subject that can deter-

1 W. Reinicke, J.M. Witte, Interdependence, Globalization, and Sovereignty: The Role of Non-binding International Legal Accords, in Commitment and Compliance: The Role of Non-Binding Norms in the International Legal System, ed. D. Shelton, Oxford 2003, p. 75.

2 F. Snyder, Soft Law and International Practice in the European Community, in The Construction of Europe: Essays in Honour of Emile Noël, ed. S. Martin, Dordrecht 1994, pp. 197, 198.

3 W. Reinicke, J.M. Witte, Interdependence, Globalization, and Sovereignty..., op. cit., p. 75.

4 F. Snyder, Soft Law and International Practice..., op. cit., pp. 197, 198.

5 D. Trubek, P. Cottrell, M. Nance, Soft Law, Hard Law and European Integration: Toward a Theory of Hybridity, "University of Wisconsin Legal Studies Research Paper" 2005, no. 1002, p. 71.

6 B Kingsbury, The Concept of Compliance as a Function of Competing Conceptions of International Law, "Michigan Journal of International Law"1998, vol. 19, p. 345.

7 D. Trubek, P. Cottrell, M. Nance, Soft Law, Hard Law and European Integration..., op. cit., p. 71. 
mine the choice of a particular legal regime. ${ }^{8}$ In their opinion, some of the advantages of adopting soft law as a form of regulation are as follows:

- lower negotiation costs,

- less sacrifice on the part of states in terms of their sovereignty,

- greater freedom to implement international standards in domestic law systems,

- the possibility to renegotiate provisions due to changing circumstances,

- simplicity and speed of proceeding,

- work on creating new regulations is open to other participants in international relations,

- the possibility of establishing a basis for binding legal regulations that will be formulated in the future.

As institutional rationalists point out, these reasons provide a basis for selecting soft law as the form to regulate a chosen issue, with the choice conditioned by the context. This paradigm sits well with the theory of rational choice, whose author, Andrew Guzman, suggests that "soft law represents a choice by the parties to enter into a weaker form of commitment," while drawing up a model interpretation of institutional rationalism.

The concept of legalization is a development of the rationalist paradigm, as presented in The Concept of Legalization. ${ }^{10}$ The authors - Kenneth W. Abbott, Robert O. Keohane, Andrew Moravcsik, Anne-Marie Slaughter and Duncan Snidal - define legalization in international relations as varying across three dimensions:

- the precision of rules,

- obligation,

- delegation to a third party decision-maker.

The aforementioned criteria make it possible to define soft law by demonstrating that a given type of regulation is weaker in one of these three aspects. In this context, hard law "refers to legally binding obligations that are precise or can be made precise through adjudication or the issuance of detailed regulations and that delegate authority for interpreting and implementing the law." ${ }^{11}$ Whereas, in contrast "the realm of soft law begins once legal arrangements are weakened along one or more of the dimensions of obligation, precision, and delegation." ${ }^{12}$

8 Cf. C. Lipson, Why Are Some International Agreements Informal?, "International Organization" 1991, p. 45; H. Hillgenberg, A Fresh Look at Soft Law, "European Journal of International Law" 1999, no. 3, pp. 499-515.

9 A. Guzman, The Design of International Agreements, "The European Journal of International Law" 2005, vol. 16 no. 4, p. 611.

10 K. W. Abbott, R. O. Keohane, A. Moravcsik, A.M. Slaughter, D. Snidal, The Concept of Legalization, "International Organization" 2000, vol. 54, issue 3, pp. 401-419.

11 Ibidem, p. 421.

12 Ibidem, p. 422. 
96 Adam Mickiewicz University Law Review

\section{The Constructivist Concept of Soft Law}

"Unlike positivism and materialism, which take the world as it is, constructivism sees the world as a project under construction, as becoming rather than being"13 - writes Emanuel Adler, when defining the constructivist paradigm. Representatives of constructivism focus on the process of creating and implementing the standards of international law. Stressing the role of this process as the focus of interest, they attempt to fill the gap between the law described in books and the law in action, which leads them to concentrate on the aforementioned process, regardless of the emphasis in other conceptions of the distinction between soft law and hard law. They adopt this assumption when demonstrating the varied impact of legal norms on the conduct of their addressees, not only in the system of international law, but also in national systems, which are perceived as a system of binding norms in the positivist and rationalist doctrines. Legal constructivism draws inspiration from sociological theories, which view the social world as an intersubjective structure. As John Ruggie writes:

At bottom, constructivism concerns the issue of human consciousness: the role it plays in international relations, and the implications for the logic and methods of social inquiry of taking it seriously. Constructivists hold the view that the building blocks of international reality are ideational as well as material; that ideational factors have normative as well as instrumental dimensions; that they express not only individual but also collective intentionality; and that the meaning and significance of ideational factors are not independent of time and place. ${ }^{14}$

By adopting this assumption, constructivists focus on the role of law in the process of socialization, viewing the process of creating law as an opportunity to strengthen the shared system of norms.

\section{International Declaration on Human Genetic Data}

The development of the human rights system from a bioethical perspective is tied up with the policies of international organizations that focus on the new risks arising from the practical use of advances in the biological and medical sciences. The local consequences of global challenges such as genetic discrimination, attempts to enhance human beings and tamper with their integrity, or patent the human genome, required a transnational response. These actions were initiated by the United Nations, which laid the

13 E. Adler, Constructivism and International Relations Theory, in Handbook of International Relations, eds. W. Carlsnaes, T. Risse, B. Simmons, London 2002, p. 113.

14 J. Ruggie, What Makes The World Hang Together, "International Organization" 1998, no. 3, p. 52. 
foundations, in a declarative manner, for the direction in which national systems would develop. According to Janusz Symonides, questions concerning the impact of scientific progress and its technological applications on the human rights system became a subject of debate for the first time at the Human Rights Conference held in Tehran in 1968. Further international initiatives resulted in a series of papers that gave rise to declarations on the use of scientific and technological progress in the interests of peace and the benefit of mankind, which were adopted in 1975 by the United Nations General Assembly. The next step in the process of establishing international legislation that responded to the social consequences of genetic engineering was to confirm the right to use the applications of scientific progress, while at the same time addressing the risks involved. As Symonides points out, during the World Conference on Human Rights, held in Vienna in 1993, the international community clearly stated that these threats could have negative effects on dignity, integrity and human rights. Efforts to establish international regulations were intensified with the first scientific papers on genetic discrimination published by the team working under Paul Billings, and by the Human Genome Project, which aimed to determine the sequence of all the complementary pairs that make up the human genome. At that time, global problems emerged, requiring international initiatives, which were undertaken by the United Nations and the Council of Europe, and which gave rise to work on the extension of the international human rights system to the bioethical domain. One of these acts is the International Declaration on Human Genetic Data of 16 October, 2003, which is of key interest to this paper.

The International Declaration on Human Genetic Data, adopted by the General Conference of UNESCO on 16 October, 2003, ${ }^{15}$ formulates the principles that bind "in the collection, processing, use and storage of human genetic data, human proteomic data and of the biological samples from which they are derived [...] in keeping with the requirements of equality, justice and solidarity, while giving due consideration to freedom of thought and expression, including freedom of research."16

This act gives special status to human genetic data, which it describes by distinguishing their attributes. These attributes are: the ability to define individuals' genetic predispositions, the ability to influence human offspring, the cultural dimension and the status of human genetic data as an information medium, the significance of which may be identified following genetic testing. This act calls for ensuring the appropriate level of

15 V. J. Symonides, Międzynarodowe instrumenty prawne w dziedzinie bioetyki i biotechnologii, in Prawa cztowieka wobec rozwoju biotechnologii, Warszawa 2013, p. 22; A. den Exter et al., International health law and ethics, Apeldoorn - Antwerp - Portland 2009 pp. 477-487; J. A. Bovenberg, Property rights in Blood, Genes and Data. Naturally yours?, Leiden - Boston 2006, p. 12; G.I. Serour, A. R.A. Ragab, Ethics of genetic counselling, in The SAGE Handbook of Health Care Ethics, eds. R. Chadwick, H. ten Have, E. M. Meslin, London 2011, p. 153.

16 Art. 1 of the International Declaration on Human Genetic Data adopted on 16 October 2003 by the 32 session of the General Conference of UNESCO. 
98 | Adam Mickiewicz University Law Review

protection both for the data and for the biological samples from which the said data may be obtained. It defines the purposes and procedures in the collection, processing, use and storage of the data. In particular, this covers diagnostics, health care, scientific research and forensic medicine, as well as criminal and other legal proceedings. The Declaration also admits the collection, processing, use and storage of data for purposes other than those numerically listed, establishing as a condition that they are consistent with its provisions and international human rights law. Those procedures related to using human genetic data and proteomic data must meet ethical norms, while policy itself in this area should take into account the opinions expressed by society. Ethics committees play an important role in this policy. These institutions - functioning at national, regional, local and institutional levels - have been ascribed the role of consultants, expressing an opinion in the process of establishing regulations to normalise measures taken in regard to human genetic data, proteomic data, and biological samples, as well as their usage in specific projects.

A condition that has to be met for steps to be taken in respect to human genetic data is that the person concerned gives their consent. This person's will must be expressed in an informed, voluntary and direct manner, after having received information concerning the purpose of the collection, processing, use and storage of the data, regarding the consequences connected to the said data, and about being able to withdraw consent at any stage of the proceedings. Following the example of the Universal Declaration on the Human Genome and Human Rights, the International Declaration on Human Genetic Data also allows for an exception to this rule, linked to reasons of great importance for the state of health of the person concerned, in the event of the said person being unable to express their conscious consent. The Declaration establishes that such intervention is defined by domestic legislation, and must proceed in keeping with the international system for the protection of human rights, while simultaneously taking into account the overriding character of the individual's interest. The Declaration also attaches authorisations to this interest regarding counselling and the results of examinations. These are: the right to decide whether or not to be informed of the results of examinations, and the right to take advantage of expert counselling when considering the option of agreeing to undergo genetic testing. Thus not allowing individuals to have access to their own data is in principle forbidden. However, this does not apply in the case of this data being irretrievably unlinked to that person as the identifiable source, or where such access is limited due to a threat to public health or order, or to national security.

The Declaration obliges states to take measures aimed at protecting the privacy of genetic data through the establishing of domestic legislation consistent with international human rights law. In this context it formulates a set of directives embracing the following: 
Soft Law in International Governance 99

- a prohibition on the disclosure or rendering accessible of human genetic data, proteomic data or biological samples linked to an identifiable person to third parties, ${ }^{17}$

- a requirement not to link human genetic data, proteomic data or biological samples collected for scientific research purposes to an identifiable person, with the exception of cases where this is essential for the nature of the research, while simultaneously ensuring protection of the privacy of these data and restricting their period of storage to the essential minimum, ${ }^{18}$

- a requirement for persons and organizational units responsible for the processing of both data and biological samples to ensure their accuracy, credibility, security and quality. ${ }^{19}$

The principles of international collaboration in regard to the circulation of data and samples are defined by three directives:

- a requirement for states to regulate the circulation of human genetic data, proteomic data and biological samples in accordance with national and international legislation, and in a manner ensuring fair access to these data, ${ }^{20}$

- a requirement for states to make every effort in regard to fostering the international dissemination of scientific knowledge related to human genetic data and proteomic data, ${ }^{21}$

- a requirement for scientists to make every effort towards establishing collaboration in regard to human genetic data and proteomic data, subject to the restrictions expressed in this Declaration. ${ }^{22}$

This collaboration involves the requirement to share the results of scientific research using human genetic data, proteomic data or biological samples, both with society and the international community, subject to the restrictions contained in domestic legislation and international agreements. The following are example ways of achieving this goal:

- establishing forms of special assistance provided to individual persons and groups participating in the research,

- guaranteeing access to medical care,

- using the research results to ensure new diagnostic methods, means of treatment, and drugs,

- providing support for the health service,

- providing research assistance for developing countries,

17 Art. 14 letter b.

18 Art. 14 letters c, d.

19 Art. 15.

20 Art. 18 letter a.

21 Art. 14 letter b.

22 Art. 14 letter c. 
100 | Adam Mickiewicz University Law Review

- other forms of action in keeping with the principles of this Declaration.

The principles of access, protection of privacy, and the demands placed before institutions involved in the processing of human genetic data, proteomic data and biological samples, also define the purpose of their use. In order for there to be a change in the purpose of using genetic data, proteomic data and biological samples, there must be sufficient grounds for public interest. As such, the Declaration allows for an exception to the prohibition on changing the purpose of their use. The samples may be used for data generation based on previously-obtained consent expressed in an informed, voluntary and direct manner by the person concerned.

\section{Human Genetic Data. From International Soft Law to Domestic Legal System}

The programmatic goals of soft law are pursued in a variety of ways by different countries in the international community. Among the examples of initiatives undertaken in this regard, it is worth mentioning the American, German and French approaches to some of the problems associated with the protection of genetic information. Both the United States and Germany have undertaken similar measures in line with international law on the protection of genetic information. The US Genetic Information Nondiscrimination Act of 21 May, $2008^{23}$ deals with unequal treatment - in the fields of health insurance and employment - that is based on genetic information, defined as information gleaned from diagnostic tests and the history of family illness. Title I of this threepart act includes provisions that cover the issue of allowances, the payment of costs and the guarantee that compensation will be made in the event of damage in the insurance sector. Title II prohibits the use of genetic information by employers in making decisions on employment, promotion, working conditions and contractual arrangements, as well as employee privileges. Similarly to US law, the German Genetic Diagnostics Act of 31 April, $2009^{24}$ also contains provisions on the use of genetic information in the context of social security and employment. This law not only prohibits genetic discrimination, as the US law does, but also makes it mandatory for the healthcare system to inform individuals who are interested in undergoing diagnosis about the possible social risks related to genetic testing, and to offer counselling in this regard.

In contrast to the German and American models, in the French system legal issues related to genetic testing are covered in Book I, Title I, Chapter III of the French Civil Code and in the Public Health Code. The French Civil Code limits the use of genetic tests to medical and scientific purposes, and in these cases the written consent of the

23 Genetic Information Nondiscrimination Act 21 May 2008, 122 Stat. 881, Public Law 110-233, May 21, 2008.

24 Gesetz über Genetische Untersuchungen bei Menschen, 31 April 2009. 
person undergoing the test is a mandatory requirement. The detailed provisions on genetic testing, developed and elaborated in the French Civil Code, are set out in the Public Health Code. Chapter I of the Public Health Code stipulates the scope of the information that must be provided prior to the test and outlines the rules for reporting the results of such tests. The only person authorized to convey the result of a genetic test is the doctor who issued the referral for it. French law respects the right - expressed in the soft law provisions of international public law - to refuse to provide information on the results. Derogation from this principle is permitted, and crucial, in the case of serious genetic abnormalities, where the doctor is required to provide such information to the person concerned, or to his or her statutory representative. The French legislator has stipulated a detailed procedure for providing information to the family, involving both the doctor and the Biomedicine Agency. Such derogation from medical confidentiality results from the need to explain genetic implications to the tested person's family. Chapter II of the Public Health Code covers the profession of genetic counsellor, a role which can only be performed in authorized health centres, both private and public. The provisions of Chapter II also impose penalties for engaging in this work without the necessary permission.

\section{Conclusion}

This outline highlights the significance of the role of international soft law instruments in tackling global challenges that require supranational initiatives. Assessing the impact of soft law instruments on the legislative practice of selected countries in the international community, and thus assessing the way the provisions resulting from international programmatic norms are implemented, was preceded by an attempt to define the meaning of soft international law from a theoretical perspective. The brief introduction presented three ways of conceptualizing the notion of soft law in the legal sciences positivist, rationalistic and constructivist. The first defines soft law by adopting a binary criterion that distinguishes two regimes of public international law, and defines soft law as non-binding. The second defines soft law in terms of the choice made by the international community, highlighting the benefits of adopting this legal regime. With the third way, the focus is on the process of creating and implementing the standards of international law, by addressing the issue of law in the context of socialization as means of strengthening the shared system of norms. Through adopting the perspective of institutional rationalism extended to the paradigm of legalism, the study considers the implementation of international standards in the field of genetic data protection in selected legal systems. These initiatives, undertaken by Germany, the United States of America and France, highlight the role of the choices made by the states of the international community when it comes to addressing the local effects of global, civilizational challenges. 
102 | Adam Mickiewicz University Law Review

\section{Literature}

Abbott K.W., Keohane R. O., Moravcsik A., Slaughter A.M., Snidal D., The Concept of Legalization, "International Organization" 2000, vol. 54, issue 3.

Adler E., Constructivism and International Relations Theory, in Handbook of International Relations, eds. W. Carlsnaes, T. Risse, B. Simmons, London 2002.

Bovenberg J.A., Property rights in Blood, Genes and Data. Naturally yours?, Leiden - Boston 2006.

Exter A. den et al., International health law and ethics, Apeldoorn - Antwerp - Portland 2009.

Guzman A., The Design of International Agreements, "The European Journal of International Law" 2005, vol. 16, no. 4.

Hillgenberg H., A Fresh Look at Soft Law, "European Journal of International Law"1999, no. 3 .

Lipson C., Why Are Some International Agreements Informal?, "International Organization" 1991.

Kingsbury B., The Concept of Compliance as a Function of Competing Conceptions of International Law, "Michigan Journal of International Law"1998, vol. 19.

Reinicke W., Witte J.M., Interdependence, Globalization, and Sovereignty: The Role of Non-binding International Legal Accords, in Commitment and Compliance: The Role of Non-Binding Norms in the International Legal System, ed. D. Shelton, Oxford 2003.

Ruggie J., What Makes The World Hang Together, "International Organization"1998, no. 3. Snyder F., Soft Law and International Practice in the European Community, in The Construction of Europe: Essays in Honour of Emile Noël, ed. S. Martin, Dordrecht 1994.

Trubek D., Cottrell P., Nance M., Soft Law, Hard Law and European Integration: Toward a Theory of Hybridity, "University of Wisconsin Legal Studies Research Paper" 2005, no. 1002 .

Serour G.I., Ragab A. R.A., Ethics of genetic counselling, in The SAGE Handbook of Health Care Ethics, eds. R. Chadwick, H. ten Have, E. M. Meslin, London 2011.

Symonides J., Międzynarodowe instrumenty prawne w dziedzinie bioetyki i biotechnologii, in Prawa cztowieka wobec rozwoju biotechnologii, Warszawa 2013.

Genetic Information Nondiscrimination Act 21 May 2008, 122 stat. 881, Public Law 110-233, May 21, 2008.

Gesetz über Genetische Untersuchungen bei Menschen, 31 April 2009.

International Declaration on Human Genetic Data adopted on 16 October 2003 by the 32 Session of the General Conference of UNESCO. 


\section{SUMMARY}

\section{Soft Law in International Governance}

The purpose of the article is to assess how the provisions resulting from international programmatic norms in the field of human genetic data are implemented. The presented study, adopting the perspective of institutional rationalism extended to the paradigm of legalism, considers examples of the implementation of these standards in selected legal systems - Germany, the United States of America and France. The selection of the research paradigm is preceded by a theoretical introduction, which presents three ways of conceptualizing the notion of soft law in the legal sciences. Following an outline of this legal regime in positivism, and the theories of rationalization and constructivism, the author focuses on the provisions of the International Declaration on Human Genetic Data of 16 October, 2003, which are compared with the legislative initiatives of Germany, the United States of America and France, to show the influence that the choices of states has on selection of the implemented standards and how they are implemented.

Keywords: public international law, soft law, human genetic data

Pawee Kwiat kowski, University of Gdańsk, Faculty of Law and Administration, Bażyńskiego 6, Gdańsk 80-309, Republic of Poland, e-mail: pawel.kwiatkowski@prawo. ug.edu.pl. 